\title{
The Effectiveness of Group Counselling with Monopoly Game Media to Improve the Students' Self-Confidence
}

\author{
Astiwi Kurniati $^{1 *}$, Paramita Nuraini ${ }^{1}$ \\ ${ }^{1}$ Faculty of Teacher Training and Education, Universitas Muhammadiyah Magelang, Magelang, Indonesia \\ "Corresponding author.Email: astiwi14@ummgl.ac.id
}

\begin{abstract}
This current study aims at investigating the effectiveness of guidance and counselling with monopoly game media to improve to self-confidence of students in SMA Muhammadiyah 1 Magelang City. To do so, it employs experimental study with AOD (After Only Design). The result showed that guidance and counselling with monopoly game effectively improve the students' self-confidence. It was proven from the difference scores of self-confidence scale between experimental and control group in which the improvement of the experimental group is greater than the control group. The result of Paired sample Test showed significance coefficient $0.001<0.05$, indicating that guidance and counselling with monopoly media is effective to improve the students' self-confidence in SMA Muhammadiyah 1 Magelang City. The implications of increasing self- confidence, look increasingly human, increasing communication skills, believing in selfreliance and being able to think positively.
\end{abstract}

Keywords: group counselling, monopoly game media, students' self-confidence

\section{INTRODUCTION}

Nowadays, many people are well-educated and look like promising one, but their careers are hampered and, even worse, knocked out due to the low emotional intelligence. People with high self-confidence will be sure about their own abilities and have realistic expectations; even when their expectations are not realized, they still think positively and can accept the situation. People with low selfconfidence, however, will feel afraid and hesitant to perform, socialize, exhibit their ability, and share opinions with others wherever they are.

Self-confidence level can only be felt by the people possessed. Other people, however, can judge someone's confidence from his behavior. Other people can notice the signs of low confidence from the behaviors in form of trembling, silence, doubt, anxiety, having no initiative, not daring to appear in front of the crowd, lacking attention to work, and blaming the atmosphere if he fails.

Monopoly games can be an alternative in conducting guidance and counselling, particularly for group counselling. By applying this game, the group's members will not get bored in the group counselling that usually takes a long time. At the end, group dynamics as the essence of group counselling can be well-established. In this study, researchers employ monopoly game as the media to improve the students' self-confidence.

Based on the result of preliminary study conducted through interview with the counselling teachers and students, researchers find that some students in SMA Muhammadiyah 1 Magelang have low confidence indicated from students' hesitance when they are asked by teachers, when they enter the teachers' room, when they have to speak in front of their friends, and the number of students who cheat during exam because of their low confidence on their ability, and so on. So far, the counselling services provided to the students is less optimal because the rarity of the counselling practices. If it is conducted, it is usually conducted conventionally. The result of study entitled "The Effect of Learning Strategy and Self Confidence Toward Student's Learning Outcomes in Elementary School" reveals that high self-confidence can improve the learning outcomes [1]. The study supports the basis of our current research that high self-confidence will provide positive effects on students' education. Other similar research entitled "Education Effect of Self-Confidence on Academic Achievement of Children At Elementary Stage Verma Saroj Kumari Principal, Shri Krishana College of Education, Pali (Mohindergarh) shows that high self-confidence improve the students' academic achievement with no significant difference in gender difference [2]. It was an experimental study which reveals that self-confidence provides a great contribution in students' academic achievement.

The other similar research is International Students' Confidence and Academic Success [3]. This research mentions that international university students who have high self-confidence in finishing the study obtain good achievements in the result of analysis also reveal that the students with low self-confidence in finishing the study obtain low achievements in academics and are not able to finish their study on time. It shows that self-confidence can realize their expectation, and therefore, one of someone's success factors is his self-confidence. Research Using Communicative Games in Improving Students 'Speaking Skills tells that communicative games give positive effects on students' speaking skill in senior high school students in Jakarta [4]. The research analysis shows that the mean of pretest is $60.42-69.02$ while the mean of posttest is 78.77 . It is important to highlight the significant improvement from $13.9 \%$ to $41.7 \%$ in posttest 1 and $83.33 \%$ in posttest 2 . This research, of course, supports our current research on 
the use of games to make the students interested, attracted and communicative during the teaching and learning process.

The other research is "Designing a Game Based on Monopoly as a learning Toll for Lodging Development" [5]. The result of this study exhibits that monopoly game is effective to be media for students' learning. The next similar research is "Influence of CTL Model by Using Monopoly Game Media to The Students' Motivation and Science Learning Outcomes Faudany" [6]. The results of this study were: (1) there was a difference between the students' learning outcomes through CTL with monopoly media and students' learning outcomes without monopoly media (NGain $=0.71)$; (2) there was a difference between the students' learning outcomes through CTL with monopoly media and students' learning outcomes through CLT without monopoly media $\left.\left(\mathrm{t}_{\text {count }}=7.876>\mathrm{t}_{\text {table }} 2.042\right)\right)$, and the improvement of students' learning motivation in the experimental group was greater than the control group by which it was only $51 \%$ before the treatment and became $86 \%$ after the treatment; (3) The result of multiple linear regressions in students' learning outcomes of science was 0.000 and students' learning motivation was 0.000 . This significant result was less than significance of 0.05 indicating that there is an influence of the use of CLT method with monopoly game media on the students' learning motivation and learning outcomes of science.

The next research is "Creating a Modified Monopoly game for promoting students' higher-order thinking skills and knowledge retention" [7], revealing that modified monopoly game effectively improves the high order thinking skills (HOTs) and students' knowledge retention. It also proves that monopoly game makes the respondent enthusiastic in group activity. From all of those researches, it can be concluded that guidance and counselling services in schools must be conducted creatively. Creativity from the teachers or counselors is important to achieve the goals of counselling services. The conventional one-way lectures of counselling form will slowly be shifted to counselling services applied innovative media that produce more optimal results. The goal of this research is increased selfconfident.

\section{METHOD}

This study employed quasi experimental research with pretest-posttest design. The students' self-confidence was measured by using self-confidence scale. All subjects of research were put into the experimental group without any control group (One Group Pretest-Posttest Design). The experimental group got treatment in form of group counselling with monopoly game to improve the students' self-confidence.

Table 1 One group pretest-posttest design

\begin{tabular}{|cccc|}
\hline Group & Pre-test & Treatment & Post-test \\
\hline Experiment & $O 1$ & $\mathrm{X}$ & $O 2$ \\
\hline
\end{tabular}

Notes:

O1: Pretest

$\mathrm{O} 2$ : Posttest

$\mathrm{X}$ : treatment (group counselling with monopoly game). It used purposive sampling technique to choose the sample.

The chosen sample is aimed to achieve certain goals, namely to improve the students' self-confidence. The subject of the research was students in second grade of SMA Muhammadiyah 1 Magelang. After the data were completely and systematically collected, it was then analyzed to obtain conclusion based on facts by using statistical calculation, which is a scientific way to gather, present, compile, and analyze numerical data. The data were analyzed by using Paired Sample t-Test. The use of Paired Sample t-Testis because it this study only involves one independent variable. The program used to calculate and run the analysis was SPSS for Windows Version 23.0.

\section{RESULTS AND DISCUSSION}

The hypothesis testing used significance coefficient. If the significance coefficient is $>0.05$, Ho is accepted, while if the significance coefficient is $\leq 0.05$, Ho is rejected. The result of Paired Samples Test is shown below.

Table 2 Paired samples test

\begin{tabular}{|c|c|c|c|c|c|c|c|c|c|}
\hline & & \multicolumn{5}{|c|}{ Paired Differences } & \multirow[b]{3}{*}{$\mathrm{t}$} & \multirow[b]{3}{*}{$\mathrm{df}$} & \multirow{3}{*}{$\begin{array}{l}\text { Sig(2- } \\
\text { tailed) }\end{array}$} \\
\hline & & \multirow[b]{2}{*}{ Mean } & \multirow{2}{*}{$\begin{array}{c}\text { Std } \\
\text { Deviation }\end{array}$} & \multirow{2}{*}{$\begin{array}{c}\text { Std Error } \\
\text { Mean }\end{array}$} & \multicolumn{2}{|c|}{$\begin{array}{c}95 \% \text { Confidence } \\
\text { Interval of the } \\
\text { Diference }\end{array}$} & & & \\
\hline & & & & & Lower & Upper & & & \\
\hline $\mathrm{Pa}$ & Before Treatment & & & & & & & & \multirow[b]{2}{*}{7.001} \\
\hline \multirow[t]{3}{*}{1} & $n-$ & - & 11.747 & 4.153 & -32.321 & -12.679 & -5.417 & & \\
\hline & After Treatment & 22.500 & & & & & & & \\
\hline & $n$ & & & & & & & & \\
\hline
\end{tabular}

Table 2 shows that the significance coefficient 0.001 is less than 0.05 , and thus Ho is rejected. Therefore, it can be concluded that group counselling with monopoly game as media is effective to improve the students' self-confidence. 


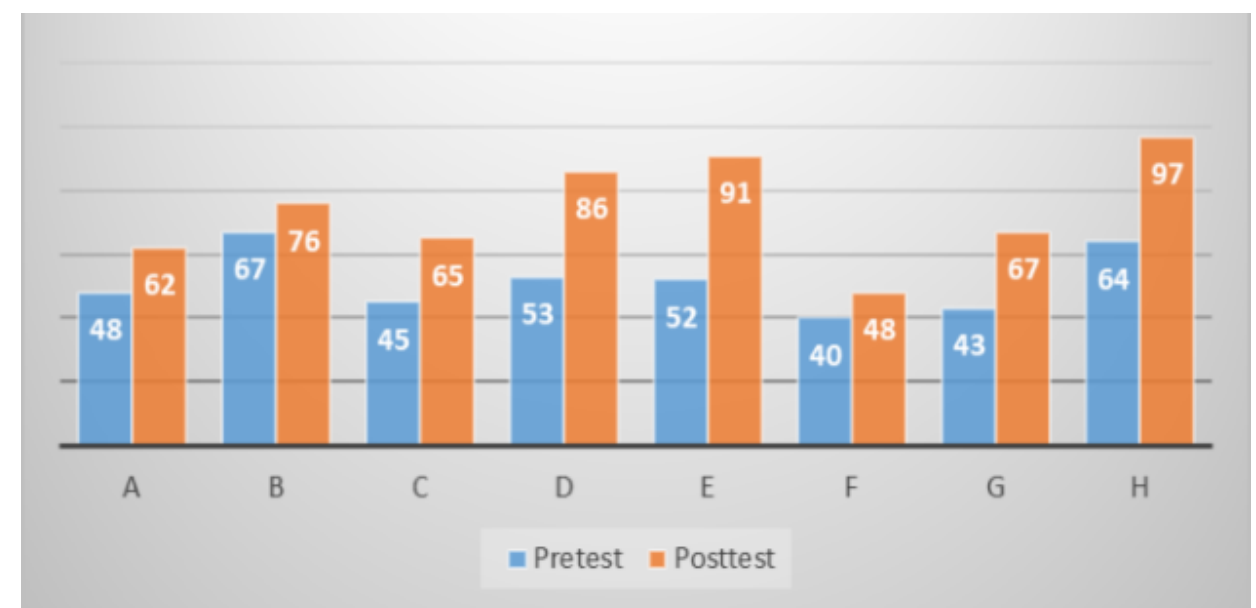

Figure 1 Comparison of pretest and posttest result

The chart discloses that interesting and creative group counselling according to the teenage dynamics will result in the positive change on the students' behaviors and attitudes. This study starts from the real condition of the existence of students with low self-confidence. For example, they are trembling when speaking in front the class., silent all the time, and difficult to express opinions. The researchers implement the group counselling with monopoly media where all group's members are required to actively engaged and interact with the other members and perform all instruction series on monopoly in a fun activity so that gradually the students can start to feel comfortable to speak, share opinions. The students also start to show good communication skills and have self-confidence as well.

\section{CONCLUSION}

The results show that the algorithm of the index for research contribution can be appropriately used to ensure the fairness of honorarium distribution. This study also found that the amount of honorarium depends on its contribution. The more contributions in research, the higher the honorarium earned, and vice versa. Furthermore, the contribution score that develops on the algorithm depends on the factor set by the authority even though the assumptions that the authors offer have reflected the entire research process.

\section{REFERENCES}

[1] L. Sihotang, D. Setiawan, and D. Saragi, "the effect of learning strategy and self-confidence toward student's learning outcomes in elementary school," J. Res. method Educ., vol. 7, no. 4, pp. 65-72, 2017.

[2] Rohtas kumar Verma and S. Kumari, "effect of selfconfidece on academic achievement of childern at elementary stage," education, vol. 5, no. 1, pp. 181$183,2016$.

[3] N. M. Telbis, "International Students' Confidence and Academic Success," vol. 4, no. 4, pp. 330-341, 2014.

[4] R. S. Dewi, U. Kultsum, and A. Armadi, "Using Communicative Games in Improving Students \' Speaking Skills," vol. 10, no. 1, pp. 63-71, 2017.

[5] R. O'halloran and C. Deale, “designing a game based on monopoly as a learning tool for lodging development," J. Hosp. Tour. Educ., vol. 22, no. 3, pp. 35-48, 2010.

[6] F. Agustiya, A. Sunarso, and S. Haryani, "influence of CTL model by using monopoly game media to the student motivation and science learning outcomes," J. Prim. Educ., vol. 6, no. 2, pp. 114-119, 2017.

[7] T. M. Kuang, “creating a modified monop oly game for promoting students' higher-oreder thingking skills and knowlegdge retention tan ming kuang a thesis subsmitted for the degree og doctor of philosophy at the university of otago, dunedin, acknowledgement," 2018. 